\title{
Forest site classification in Canada: A current perspective Classification des sites forestiers au Canada - perspective actuelle
}

\author{
Introduction \\ by/par R.A. Sims ${ }^{1}$
}

\begin{abstract}
Forestry Canada's Forest Site Classification Working Group was founded in 1986. It was to be a forum for federal site classification researchers and others, with regularly scheduled meetings to discuss activities and research interests, share ideas and concerns, and collaborate on group projects. The Working Group acted as the initial catalyst for the preparation of this set of papers.
\end{abstract}

The Working Group continues to be active. In 1990 its mandate was expanded to include the scientific direction and management of several Forest Land Classification initiatives under the Forestry Canada Science and Technology component of the federal Green Plan. The Group is undertaking a number of nationally oriented projects that include plans for a major conference on forest site classification in 1994, as well as the preparation of training materials on site classification and the completion of publications and reports on several topics. New site classification research will be also be undertaken, some of it affiliated with Model Forests a major initiative under the Green Plan. Through such venues, the Working Group will attempt to expand the knowledge base on forest site classification in Canada.

The following papers provide nine regional treatments on site classification, preceded by a particularly insightful overview by Stan Rowe. Together, the package offers a snapshot of current site classification activities in various parts of Canada. It is not a complete picture, of course: some provinces are not covered, and there are other site classification activities at stages still too early to report. Moreover there is a wide spectrum of overlap between what is generally discussed in these papers, namely "forest land description, classification and mapping," and various other broad subject areas such as silviculture, phytosociology, soil science, geomorphology, geomatics and remote sensing. This situation makes it very difficult to draw the line on what to include or exclude from a comprehensive treatment of forest site classification.

This collection should serve to stimulate awareness of and interest in the considerable amount of current activity in forest site classification. This set of papers is perhaps especially timely, as a pan-Canadian status report on site classification activities has not been produced since the Conference on Ecological Classification at UBC in 1977. Several recent symposia and researchers have dealt with important site classification issues: Bockheim in 1984 and van Groenewoud in 1986, on general philosophy and methodology; Wickware and Stevens in 1986 and Mengel and Tew in 1991, on applied forest management. None, however, has included the Canadian cross-country update of activities provided here.

\footnotetext{
${ }^{1}$ Chair, Forest Site Classification Working Group, Forestry Canada - Ontario Region, Great Lakes Forestry Centre, P.O. Box 490, Sault Ste Marie, Ontario P6A 5 M7.
}

Le groupe de travail de Forêts Canada sur la classification des sites a été fondé en 1986 pour servir de lieu de rencontre régulier entre les spécialistes fédéraux de la recherche sur la classification des sites et d'autres chercheurs, afin qu'ils puissent discuter de leurs activités et de leurs recherches, communiquer leurs idées et leurs points d'intérêt, et collaborer à des projets de groupes. Le groupe de travail a été le point de départ de la présente série d'articles.

Le groupe de travail poursuit ses activités et a vu son mandat s'élargir en 1990 pour inclure la direction scientifique et la gestion de plusieurs projets de classification des terres forestières; ce travail représente l'apport scientifique et technologique de Forêts Canada au Plan vert du gouvernement fédéral. Le groupe de travail entreprend un certain nombre de projets d'envergure nationale qui comprennent la préparation d'une importante conférence sur la classification des sites forestiers en 1994, ainsi que la création de matériel de formation sur la classification des sites, de publications et de rapports sur divers sujets. De nouvelles recherches sur la classification des sites seront également entreprises, en partie dans le cadre des forêts modèles, une des grandes initiatives du Plan vert. Le groupe de travail s'efforce ainsi d'augmenter notre connaissance en matière de classification des sites forestiers au Canada.

Les articles qui suivent représentent neuf perspectives régionales de la classification des sites. Ils sont précédés d'un avant-propos particulièrement probant de Stan Rowe. Dans leur ensemble, ces articles offrent un coup d'œil des opérations de classification des sites pratiquées actuellement dans diverses régions du Canada. Il ne s'agit pas d'une image complète, bien sûr, puisque certaines provinces ne sont pas mentionnées; tandis que d'autres opérations de classification ne sont pas à un stade assez avancé pour être rapportées. Il faut ajouter que les sujets abordés dans ces articles, soit la description des terres forestières, la classification et la cartographie, recouvrent en partie d'autres domaines généraux comme la sylviculture, la phytosociologie, la science des sols, la géomorphologie, la géomatique et la télédétection. Il est donc très difficile de fixer les limites d'une classification des sites forestiers qui soit complète.

La lecture de ces articles permettra non seulement de découvrir l'étendue des activités qui se rapportent à la classification des sites forestiers, mais elle pourrait également susciter un intérêt plus vif envers ce sujet. Alors, cette publication arrive peut-être au bon moment puisque l'on n'a pas produit de rapport d'étape sur la classification des sites forestiers à l'échelle du Canada depuis la conférence sur la classification écologique tenue à l'université de Colombie-

\footnotetext{
${ }^{1}$ Directeur, Groupe de travail sur la classification des sites forestiers Forêts Canada, Région de l'Ontario, Centre de foresterie des Grands Lacs, Boîte postale 490, Sault Ste. Marie (Ontario) P6A 5M7
} 
As Burger and Pierpoint aptly noted in 1990, classification is only a means to an end: the usefulness of site classifiations as forest management tools ultimately lies in how they are implemented, applied and built upon. Certainly, it is clear from this set of papers that the current, quantitatively based site classification systems, are beginning to occupy important new roles in operational forest management across Canada. Undoubtedly, their use will increase in the future.

It is also clear that different parts of the country are at different stages in the implementation and development of forest site classification systems, and that philosophies and approaches have varied. As Rowe points out in his prologue to these papers, this is not of particular concern or consequence. There is, however, a need for the development of certain "equivalences" of terminologies to draw together the common threads that do exist. Forestry Canada's Forest Site Classification Working Group will continue to play a role in these activities over the coming years.

In conclusion, I should mention that the papers in this collection were not subjected to the Forestry Chronicle's standard review process; rather, prior to their submission, the papers underwent a formal peer review and edit by members of the Working Group and others. To those that assisted in this process, I extend my sincere thanks.

Britannique en 1977. Récemment, plusieurs colloques et chercheurs ont traité d'importantes questions portant sur la classification des sites, telles les concepts, l'attitude générale et la méthodologie (Bockheim en 1984, et van Groenewoud en 1986), et l'aménagement appliqué des forêts (Wickware et Stevens en 1986, et Mengel et Tew en 1991). Cependant, aucun d'eux n'a présenté une mise à jour des activités à l'échelle du Canada comme celle que l'on obtient ici.

Comme Burger et Pierpoint (1990) l'ont si bien remarqué en 1990, la classification n'est qu'un outil. Son utilité dans l'aménagement des forêts est déterminée, en dernier ressort, par la façon dont elle est mise en œuvre, appliquée et développée. Il apparaît très clairement dans ces articles que les systèmes quantitatifs actuels de classification des sites commencent à jouer de nouveaux rôles importants dans l'aménagement opérationnel des forêts au Canada, tendance qui ne pourra sans doute que s'accentuer dans l'avenir.

En outre, il ressort clairement que les étapes de mise en œuvre et de développement de systèmes de classification des sites forestiers varient de région en région à travers le pays, et que les attitudes générales et les méthodes utilisées varient également. Mais comme S. Rowe l'indique dans son avantpropos, cela ne pose pas de problème particulier. Cependant, le besoin se fait sentir d' 'équivalences" dans la terminologie afin de rapprocher les éléments communs qui existent déjà. Le groupe de travail sur la classification des sites forestiers de Forêts Canada continuera à œuvrer en ce sens à l'avenir.

Finalement, il faudrait mentionner que les articles de cette publication n'ont pas été l'objet du processus habituel de révision de The Forestry Chronicle; ce sont les membres du groupe de travail et d'autres spécialistes qui ont entrepris la révision et la correction des articles, avant de les soumettre. Je tiens à remercier sincèrement tous ceux qui ont participé à cet effort.

\section{Prologue/Avant-propos by/par J. Stan Rowe ${ }^{1}$}

Forestry in Canada has a 65-year tradition of site classification whose beginning in the late 1920s is associated with the visit to North America of Ilvessalo, a student of Cajander, the Finnish ecologist. The discovery was made that in the simply structured boreal forests of Fenno-Scandia and Canada the minor vegetation showed a close correlation with soil moisture-nutrient regimes - a vital clue to the potential productivity of the spruce, pine, birch and poplar overstory. For thirty years "site classification" meant identification of indicator plant communities, and foresters were encouraged to know their plants by such justly famous people as Brinkman, Halliday, Heimburger, Rousseau, Lafond, Linteau, Ray, Lossee, Sisam and Spilsbury.

This phytosociological phase began to wane in the 1950s and 1960s with the appearance in Ontario forests of a soil surveyor, Angus Hills, who more than anyone else turned the attention of research foresters to the previously unseen substratum in which trees and minor vegetation are rooted. Stressing the importance of physiography, Hills and his students eventually developed a total site or ecosystem approach

\footnotetext{
'Professor Emeritus, University of Saskatchewan, Saskatoon, Saskatchewan, S7N 0W0. 1012 Josephine Street, New Denver, British Columbia, VOG 150
}

La classification des sites forestiers au Canada a commencé il y a soixante-cinq ans. Ses débuts correspondent à la visite, à la fin des années 1920, d'Ilvessalo, étudiant de l'écologiste finnois Cajander. On a découvert que dans les forêts boréales finno-scandinaves et canadiennes aux structures très simples, la menue végétation était étroitement liée à l'humidité et aux éléments nutritifs du sol, ce qui laissait supposer le potentiel productif de l'épinette, du pin, du bouleau et du peuplier. Pendant trente ans, la "classification des sites" était synonyme d'identification des communautés végétales indicatrices, et des gens aussi célèbres que Brinkman, Halliday, Heimburger, Rousseau, Lafond, Linteau, Ray, Lossee, Sisam et Spilsbury encourageaient les forestiers à "connaître leurs plantes".

Cette phase phytosociologique a commencé son déclin dans les années 1950 et 1960 avec l'arrivée dans les forêts ontariennes du topographe Angus Hill. C'est lui qui, plus que tout autre, a attiré l'attention des chercheurs forestiers sur le sous-sol, jusque-là «inexistant", dans lequel les arbres et la menue végétation prennent racine. En mettant l'accent

\footnotetext{
'Professeur émérite, Université de la Saskatchewan, Saskatoon, Saskatchewan, S7N 0W0, 1012, rue Josephine, New Denver (Colombie-Britannique) VOG 1 SO
} 